\title{
Biochemical Characterization of Oligomerization of Escherichia coli GTP Cyclohydrolase I
}

\author{
Soojin Lee, Chiyoung Ahn, Eungsik Park, Deog Su Hwang and Jeongbin Yim* \\ The National Creative Research Initiative Center for Genetic Reprogramming, Institute for Molecular Biology and Genetics, \\ Seoul National University, Seoul 151-742, Korea
}

Received 25 October 2001, Accepted 23 November 2001

GTP cyclohydrolase I (E.C. 3.5.4.16) is a homodecameric protein that catalyzes the conversion of GTP to 7,8dihydroneopterin triphosphate $\left(\mathrm{H}_{2} \mathrm{NTP}\right)$, the initial step in the biosynthesis of pteridines. It was proposed that the enzyme complex could be composed of a dimer of two pentamers, or a pentamer of tightly associated dimers; then the active site of the enzyme was located at the interface of three monomers (Nar et al. 1995a, b). Using mutant enzymes that were made by site-directed mutagenesis, we showed that a decamer of GTP cyclohydrolase I should be composed of a pentamer of five dimers, and that the active site is located between dimers, as analyzed by a series of size exclusion chromatography and the reconstitution experiment. We also show that the residues Lys 136, Arg139, and Glu152 are of particular importance for the oligomerization of the enzyme complex from five dimers to a decamer.

Keywords: Decamer, Dimer, Reconstitution, Site-directed mutagenesis, Size exclusion

\section{Introduction}

GTP cyclohydrolase I (GTP CHase I) (E.C. 3.5.4.16) catalyzes the conversion of GTP to dihydroneopterin triphosphate $\left(\mathrm{H}_{2} \mathrm{NTP}\right)$, the first step in the biosynthesis of pteridine coenzymes, such as folic acid and tetrahydrobiopterin (Shiota et al., 1967; Yim and Brown, 1976; Nichol et al., 1985; Brown and Williamston, 1987; Cha et al., 1991; Ahn et al., 1995, 1997). The enzyme product, $\mathrm{H}_{2} \mathrm{NTP}$, is generally accepted as the common intermediate for all naturally-occurring pteridines.

Yim and Brown purified E. coli GTP CHase I to apparent homogeneity using a GTP-coupled affinity gel (Yim and

*To whom correspondence should be addressed.

Tel: 82-2-880-6702; Fax: 82-2-871-4315

E-mail: jyim@plaza.snu.ac.kr
Brown, 1976). They also found that the molecular mass of the active enzyme was $210 \mathrm{kDa}$, and the enzyme could dissociate into inactive subunits of $51 \mathrm{kDa}$ at high-salt. When GTP was added to the enzyme mixture at the same-salt conditions, the dissociated subunits could reassociate to the active form (Yim and Brown, 1976). These facts implied that the active site might be located at the interface of the subunits. In some enzymes, the active site is located at subunit interfaces, and catalysis often involves contributions from different subunits (Wente and Schachman, 1987; Tobias and Kahana, 1993; Frimpong and Rodwell, 1994; Ozturk et al., 1995; Wang et al., 1997; Kim et al., 2001). A particularly well-explored case is that of $E$. coli aspartate transcarbamoylase, in which case the hybrid trimers that are formed by the reconstitution of wild-type and mutant subunits were 10 times more active than the mutant parental proteins (Maley et al., 1995).

The gene that encodes GTP CHase I of E. coli was cloned and sequenced (Katzenmeier et al., 1990; Katzenmeier et al., 1991). The sequence predicts a polypeptide with 221 amino acids, and a predicted molecular mass of 24,699 Da. The protein sequence of GTP CHase I is well-conserved from organism to organism, especially in the C-terminal region. The polypeptide is predicted to contain 6 alpha-helical domains and 4 beta-sheet domains; the $\mathrm{N}$-terminal region contains 3 helical domains and the compact $\mathrm{C}$-terminal region contains the beta-sheets that are flanked by helices (Schmid et al., 1992). The crystal structure of E. coli GTP CHase I showed that the enzyme is a decamer of 250,000 MW, which is composed of 10 polypeptides of 25,000 Da (Meining et al., 1995). It was first reported that the functional enzyme is formed by a face-to-face association of two pentamers (termed A and B). Each pentamer is composed of five monomers that are joined by a cyclic arrangement of a 20 stranded antiparallel $\beta$-barrel. The enzyme complex was later described as a doughnut-shaped homodecamer that consisted of five tightly associated dimers that are arranged with fivefold symmetry (Nar et al., 1995a, b).

The X-ray crystal structure of $E$. coli GTP CHase I, where 
the active site is occupied by the substrate analog dGTP, helps to clarify the structure of the active site (Nar et al., 1995a). In the decamer, 10 equivalent active sites are present. Each of these contain a $10-\AA$ deep pocket that is formed by surface areas of 3 adjacent functional groups, each contributed by a different monomer. Functional group A (amino acids 110-113, 150-153, and 179-185) and group A' (amino acids 87-89 and 131-139) are located on one hypothetical pentamer, while group B (Arg65 and Lys68) is on the other. The active site loops within the A and A functional groups are structurally stabilized by extensive, short-range hydrogen bond interactions. They are mutually linked by a disulfide bridge (Cys110-Cys181), a salt bridge (Glu111-Arg153), and a hydrogen bond interaction (Gln151-His179). Several functional domains contribute to the binding of the substrate. First, the acceptor site for the pyrimidine portion was found at the bottom of the active site cavity. Second, Glu152 forms a salt bridge with a guanidine moiety. Third, a peptide bond between Val150 and Gln151 forms a hydrogen bond to the C4 oxo group of the purine. Fourth, a cluster of basic residues His113, Arg185, Lys136, Arg139, Arg65, and Lys68 - binds to the triphosphate group.

In this paper, we show biochemical evidence that a decamer of GTP CHase I is composed of the pentamer of five dimers, and the active site should be located between two subunits of a dimer and one subunit of another neighboring dimer. We also show the residues that are important for oligomerization of GTP CHase I from five dimers to a decamer.

\section{Materials and Methods}

Subcloning of $E$. coli GTP CHase I gene to pGEM-7Zf(+) plasmid Phagemid vector pGEM-7Zf(+) was chosen to produce single-stranded plasmid for mutagenesis. A BamHI-SacI fragment that contained the GTP CHase I structural gene and promoter region was ligated to BamHI-SacI cut pGEM-7Zf(+). This plasmid was designated as $\mathrm{pZCH}$.

Site-directed mutagenesis Site-directed mutagenesis was performed using the Kunkel method, described by Yuckenberg $e t$ al. (Yuckenberg et al., 1991). The pZCH phagemid was transformed to the E. coli RZ1032 (ung ${ }^{-}$,dut $t^{-}$) strain. A singlestranded uracil-containing pZCH was prepared by the method described by Promega (Madison, USA) and used as the template for site-directed mutagenesis. Oligonucleotides that were designed for the mutagenesis of specific amino acids were used to synthesize the second-strand DNA. Site-directed mutations of GTP CHase I clones were confirmed by DNA sequencing using a Sequenase ${ }^{\mathrm{R}}$ kit (U.S. Biochemicals).

Purification of GTP CHase I enzymes $\quad$ E. coli DH5 $\alpha$ was used to overexpress the GTP CHase I wild-type and mutant enzymes. Wild-type GTP CHase I was purified as described by Yim and Brown (1976). After ammonium sulfate fractionation (35-50\%), the enzyme mixture was applied on a column of Sephacryl 300HR $(2.5 \times 60 \mathrm{~cm})$. A GTP-sepharose column was then used to purify the enzyme.

E. coli, which carried the high-copy plasmid that contained the mutant GTP CHase I, was cultured in a Luria media in the presence of $50 \mu \mathrm{l} / \mathrm{ml}$ ampicillin. Mutant enzymes were partially purified using ammonium sulfate fractionation and gel filtration chromatography. Since mutant cells contain a chromosomal copy of wild-type GTP CHase I, the GTP-Sepharose step was omitted in order to avoid enrichment of the wild-type enzyme. In the case of inactive GTP CHase I, the presence of the enzyme was monitored by ELISA using the antibody against $E$. coli GTP CHase I. When necessary, the amount of GTP CHase I was estimated by radial immunodiffusion (Mancini et al., 1965).

Assay of GTP CHase I The fluorescence of $\mathrm{H}_{2} \mathrm{NTP}$ was measured using the method of Fukushima et al. (1977). The reaction was performed in darkness at $42^{\circ} \mathrm{C}$ for 30 min with $0.1 \mathrm{mM}$ GTP in $0.1 \mathrm{M}$ Tris-HCl, $\mathrm{pH} 8.0,0.1 \mathrm{M} \mathrm{KCl}, 5 \mathrm{mM}$ EDTA with partially purified enzymes. In the fluorescence assay, the reactions were stopped by the addition of $25 \mu 1$ of an acidic iodine solution ( $5 \mathrm{~N}$ Trichloroacetic acid: $1 \% \mathrm{I}_{2}-2 \% \mathrm{KI}=1: 5$ ). The fluorescence of neopterin triphosphate was measured using a spectrofluorometer (excitation $360 \mathrm{~nm}$; emission $450 \mathrm{~nm}$ ). One unit of GTP CHase I was defined as the amount of enzyme that is needed for the formation of 1 pmole $\mathrm{H}_{2} \mathrm{NTP}$ per min under the standard assay conditions.

Association/dissociation assay Crude extracts of GTP CHase I mutants were prepared in $400 \mu \mathrm{l}$ of $50 \mathrm{mM}$ Tris- $\mathrm{HCl}$ (pH 8.0) using a minibead beater. Crude extract was incubated at $4^{\circ} \mathrm{C}$ with GTP ( $5 \mu \mathrm{M}$ unless otherwise indicated) and/or $0.3 \mathrm{M} \mathrm{KCl}$ for $1 \mathrm{~h}$ before loading. After centrifugation at $10,000 \times g$ for $30 \mathrm{~min}$, the extracts $(0.2 \mathrm{mg}$ protein $/ 0.1 \mathrm{ml})$ were applied to a Superdex $200 \mathrm{HR} 10 / 30$ column $\left(\mathrm{V}_{\mathrm{t}}=24 \mathrm{ml}\right)$ that was previously equilibrated with $50 \mathrm{mM}$ Tris-HCl (pH 8.0), or with Tris $+0.3 \mathrm{M} \mathrm{KCl}$. Fractions of $0.25 \mathrm{ml}$ were collected at a flow rate of $0.2 \mathrm{ml} / \mathrm{min}$. The enzyme was detected by ELISA using the antibody against E.coli GTP CHase I.

\section{Results}

Activities of mutant GTP cyclohydrolase I X-ray crystallographic data showed that the active site of GTP cyclohydrolase $\mathrm{I}$ is located at the interface of three monomers (two from within one pentamer, A and A', one from the other pentamer, B), which is formed by the residues 110-113, 150153 and 179-185 (from A), 87-89 and 131-139 (from A'), and Arg65 and Lys68 (from B) $(17,18)$. To define the function of individual residues in the active site, we made a number of mutants by site-directed mutagenesis of a plasmid that directs the overexpression of GTP CHase I, then transformed them into $E$. coli cells for the production of proteins. The crude cell extracts of the mutant strains contained the same concentration of GTP CHase I as determined by the ELISA assay. The extracts were assayed for enzyme activity and the $\mathrm{pH}$ and temperature optima of mutant proteins.

All of the mutant proteins had activities lower than the wild type (Table 1). In particular, mutation in the residues 112, 135, 
Table 1. Relative specific activities and optimum $\mathrm{pH}$ and temperature of GTP CHase I mutants.

\begin{tabular}{cccc}
\hline $\begin{array}{c}\text { Mutant } \\
\text { protein }\end{array}$ & $\begin{array}{c}\text { Relative } \\
\text { specific } \\
\text { activity (\%) }\end{array}$ & pH optimum & $\begin{array}{c}\text { Temperature } \\
\text { optimum } \\
\left({ }^{\circ} \mathrm{C}\right)\end{array}$ \\
\hline Wild type & 100 & 8.5 & 60 \\
R65L & 14 & 8.5 & 72 \\
C110G & 0.22 & 8.5 & 75 \\
E111K & 3.1 & 8.5 & 85 \\
H112D & 0.23 & 7.5 & 65 \\
H113N & 67 & 8.0 & 70 \\
L134Q & 1.85 & 8.5 & 75 \\
S135C & 0.7 & 7.0 & 55 \\
K136E & 0.25 & 8.5 & 65 \\
R139C & 29.3 & 8.0 & 60 \\
V150E & 3.2 & $7.0-8.5$ & 85 \\
E152K & 0.06 & 9.0 & 45 \\
H179Q & 0.8 & 8.5 & 65 \\
C181S & 0.29 & 8.5 & 90 \\
R185G & 2.9 & 8.5 & 55 \\
\hline
\end{tabular}

GTP CHase I mutants were generated by site-directed mutagenesis and overexpressed in E. coli. The activity of mutant enzymes was measured under the standard assay conditions with $0.1 \mathrm{mM}$ GTP using the fluorescence method. The amount of GTP CHase I protein was estimated by the radial immunodiffusion method (21).

136,152 , or 179 prominently reduced the enzyme activities of proteins. In addition, mutation in the residues 110 or 181 , which are involved in the complexation of zinc (Auerbach et al., 2000), also caused a dramatic reduction in the enzyme activities. The results suggest that these residues are essential for catalytic function, which corresponds well with previous data (Nar et al., 1995b).

The temperature and $\mathrm{pH}$ optima of some mutant enzymes differed from those of the wild-type enzyme (Table 1). Maximum activity occurred at much higher temperatures in $\mathrm{E} 111 \mathrm{~K}, \mathrm{~V} 150 \mathrm{E}$, and C181S mutants. Also noteworthy is the S135C mutant, which had a $\mathrm{pH}$ optimum of about 7.0, exhibiting a sharp decrease of enzyme activity at $\mathrm{pH} 8.0$ or above. Since the $\mathrm{pK}_{\mathrm{R}}$ of Cys is about 8.3, the decrease in activity seemed to be due to the transition from $-\mathrm{SH}$ to $-\mathrm{S}^{-}$of the Cystein R group. This result suggests that the hydroxyl group of Ser 135 might play a crucial role in GTP CHase I catalysis, as previously proposed (Nar et al., 1995b).

Association and dissociation of mutant GTP cyclohydrolase I Prominent reduction of the enzyme activity by the mutation of residues in the active site can be caused by the loss of catalytic function, or the dissociation of a decamer to subunits. Yim and Brown also showed that GTP CHase I could dissociate into dimers in a buffer containing 0.3 $\mathrm{M} \mathrm{KCl}$, and reassociate by the addition of $5 \mu \mathrm{M}$ GTP at the same-salt concentration (Yim and Brown, 1976). This led us
(A)
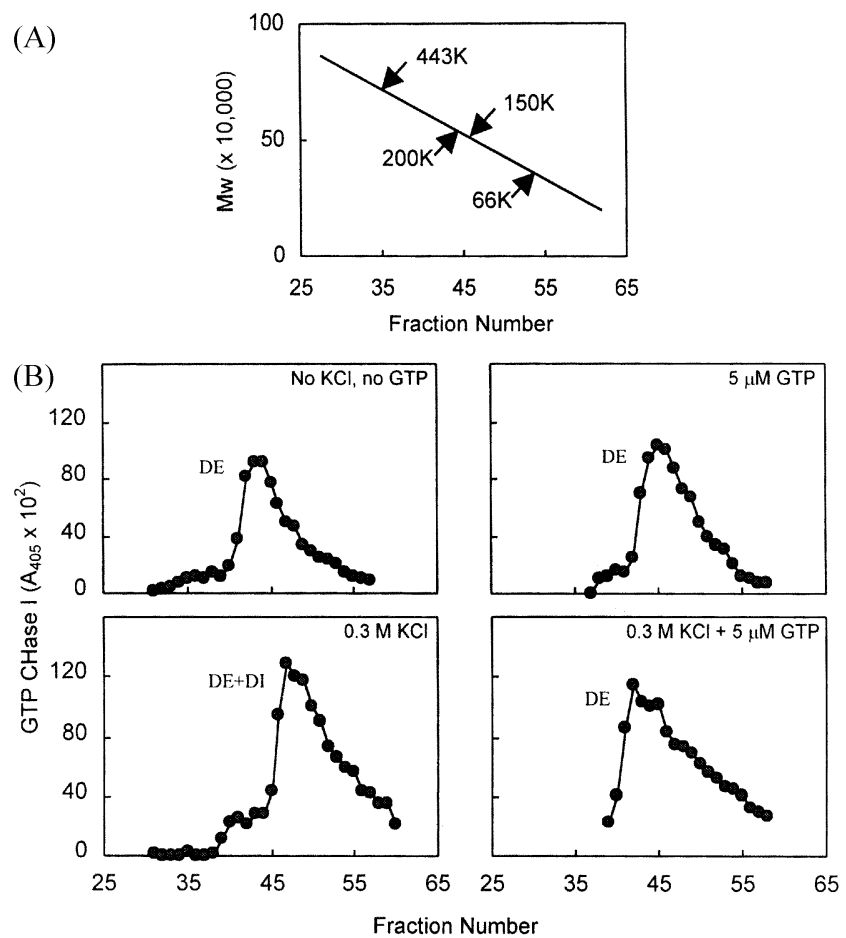

Fig. 1. Gel filtration of standard proteins and wild-type GTF CHase I. (A) The molecular weight standard proteins used wer apoferritin (443K), $\beta$-amylase $(200 \mathrm{~K})$, alcohol dehydrogenase $(150 \mathrm{~K})$, and bovine serum albumin $(66 \mathrm{~K})$. (B) The profiles o wild-type GTP CHase I. Crude extracts were incubated with no additives, or with GTP in the presence or absence of $\mathrm{KCl}$. Thr extracts were then applied to a Superdex column that wa: previously equilibrated with the same buffer. The column wa: developed as described in the Experimental Section. The enzymes were detected by ELISA using an antibody agains GTP CHase I. DE: decamer, DI: dimer, DE+DI: equilibriun between decamer and dimer.

to examine the association and dissociation aspects of mutant enzymes in order to identify residues that are involved in the oligomerization of GTP CHase I.

The crude cell extracts of wild type or mutants were applied to a Superdex column that was equipped with a FPLC system, then the migration profiles of GTP CHase I were determined by an ELISA assay. All of the experiments were performed under the same conditions. The molecular mass of the proteins in the fractions was estimated by a comparison with that of the standard proteins (Fig. 1A). A wild-type enzyme migrated as $250 \mathrm{kDa}$ species in $50 \mathrm{mM}$ Tris- $\mathrm{HCl}$, $\mathrm{pH}$ 8.0. However, in the presence of $0.3 \mathrm{M} \mathrm{KCl}$ its migration shifted to approximately $120 \mathrm{kDa}$. This indicates that a decameric structure is dissociated by an increase of ionic strength (Fig. 1B). $120 \mathrm{kDa}$ is very close to the molecular mass of a pentamer of GTP CHase I, but we believe that those were species in an equilibrium state between a decamer and dimers. When $5 \mu \mathrm{M}$ GTP was added in the elution buffer, the enzyme peak shifted back to $250 \mathrm{kDa}$. This result indicates 
that GTP stabilizes the native decameric structure.

Most of the mutant enzymes also migrated as decamers in the absence of $\mathrm{KCl}$, but some mutant enzymes (E152K, K136E, R139C, and S135C) showed abnormal migration. The E152K mutant protein eluted right after the void volume. It probably was a high molecular weight aggregate, due to denaturation that was caused by the E152K mutation, otherwise it could be a didecamer (Fig. 2A). The addition of $50 \mu \mathrm{M}$ GTP failed to return it to a decamer, explaining why it had the least enzyme activity. K136E and R139C migrated to a position of $50 \mathrm{kDa}$ proteins that were estimated as dimers. R139C converted into a decamer by the addition of $4 \mu \mathrm{M}$ GTP, while K136E was partially shifted to a decamer despite the addition of $50 \mu \mathrm{M}$ GTP. The S135C mutant protein exhibited a mixture of high molecular weight forms and decamers (Fig. 2A). When $50 \mu \mathrm{M}$ GTP was added, almost all of the high molecular weight forms of S135C were converted into decamers.

Taken together, the residues 111,135 , and 152 are likely to play some role in forming and stabilizing the native decameric structure. Noteworthy is the fact that the K136E and R139C mutant proteins were detected as dimeric subunit forms (50 $\mathrm{kDa}$ ), even in the absence of high-salt (Fig. 2B). The dissociated R139C protein reassociated completely into the native form by the addition of only $5 \mu \mathrm{M}$ GTP, while over $40 \%$ of the $\mathrm{K} 136 \mathrm{E}$ enzyme remained as a dissociated form, even in the presence of $50 \mu \mathrm{M}$ of GTP. This result corresponds with the data that the enzyme activity of R139C is relatively higher than the other mutant enzymes (Table 1). These findings strongly suggest that Lys 136 and Arg 139 are the residues that are critical in the oligomerization of subunits.

Next, we investigated the migration aspects of mutant proteins in the presence of $0.3 \mathrm{M} \mathrm{KCl}$ using the same Superdex column under the same conditions. The C110G, E111K, H112D, and C181S mutant proteins appeared in fractions at approximately $120 \mathrm{kDa}$, as found in the wild-type protein. However, unlike the wild-type protein, these mutants failed to be converted into native decamers by the addition of $5 \mu \mathrm{M}$ GTP in the presence of $0.3 \mathrm{M} \mathrm{KCl} \mathrm{(Fig.} \mathrm{3A).} \mathrm{In}$ contrast, the K136E, R139C, V150E, E152K, and H179Q mutant enzymes migrated as completely dissociated subunits in the presence of $0.3 \mathrm{M} \mathrm{KCl}$ (Fig. 3B). When $5 \mu \mathrm{M}$ GTP was added, the $\mathrm{V} 150 \mathrm{E}$ and $\mathrm{H} 179 \mathrm{Q}$ proteins reassociated into a mixed population of decamers and dimers. Interestingly, the $\mathrm{K} 136 \mathrm{E}$, R139C, and E152K mutants remained in their dimeric forms, even in the presence of $5 \mu \mathrm{M}$ GTP (Fig. 3B). These results suggest that these residues are essential for both GTP binding and oligomerization.

Reconstitution of mutant GTP cyclohydrolase I A series of size exclusion chromatography showed that wild type and some mutant proteins of GTP CHase I dissociated into catalytically inactive dimers of $50 \mathrm{kDa}$ in the presence and/or absence of $0.3 \mathrm{M} \mathrm{KCl}$. A dimer could be composed of either a pair of $\mathrm{A}$ and $\mathrm{A}$ monomers, or $\mathrm{A}$ and $\mathrm{B}$ monomers. To
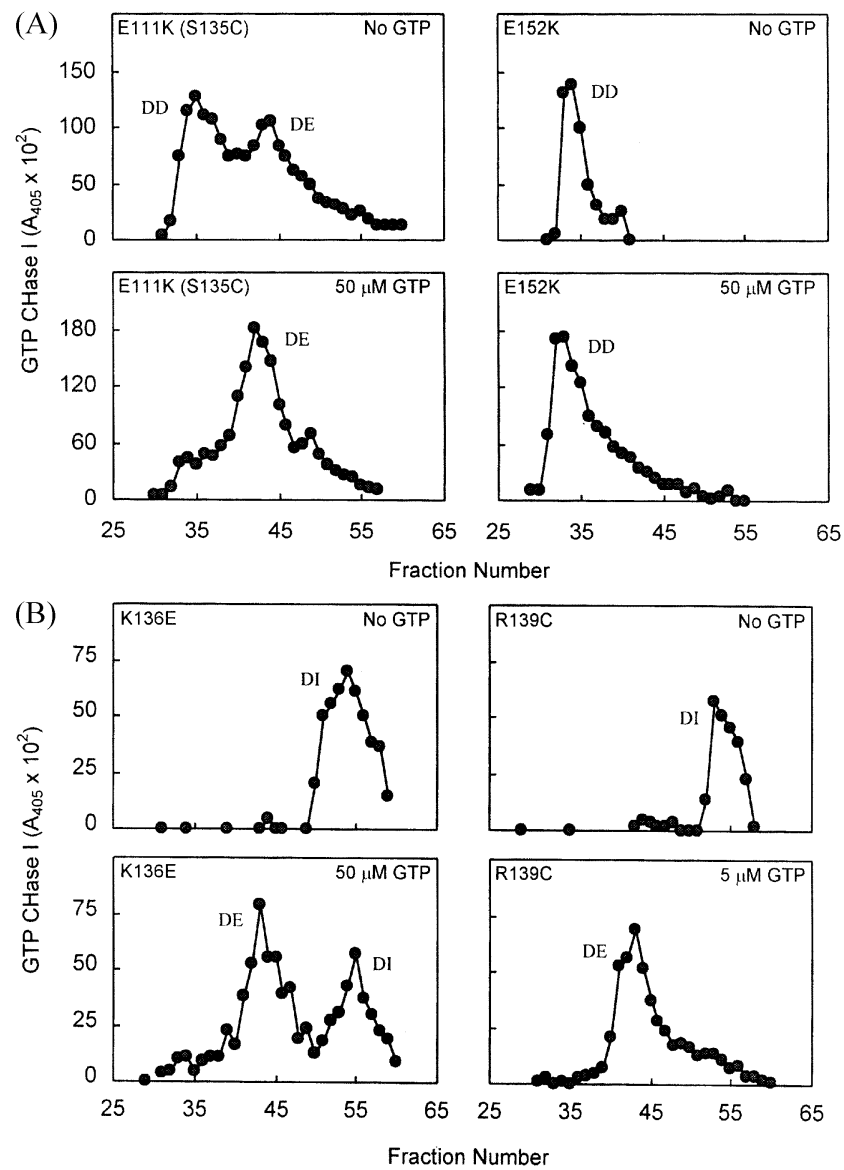

Fig. 2. Gel filtration of GTP CHase I mutants in the absence of $0.3 \mathrm{M} \mathrm{KCl}$. (A) Mutants showing high molecular weight aggregates. (B) Mutants showing 50,000 MW subunit. Crude extracts were incubated with or without GTP at the concentrations indicated, then applied to a Superdex column that was previously equilibrated with $50 \mathrm{mM}$ Tris- $\mathrm{HCl}$ in the presence or absence of GTP. The enzymes were detected by ELISA using an antibody against GTP CHase I. DD: high molecular weight aggregates, DE: decamer, DI: dimer.

examine which monomers form a dimer in the native state, a reconstitution assay was performed as follows. We first incubated mutant enzymes in $0.3 \mathrm{M} \mathrm{KCl}$ to induce dissociation. Different combinations were then made by mixing any two mutant enzymes, and $0.1 \mathrm{mM}$ GTP was added to the mixtures to induce reassociation. Finally, the enzyme activities of the mixtures were measured.

Among many mutant enzymes that were tested in this reconstitution assay, some combinations resulted in the restoration of activity. The mixtures of any two inactive mutants that carried each of the two mutations within the same active group (within A or A' functional groups, for example) exhibited no increase in enzyme activity, compared to the average of each parental mutant enzyme (Table 2a). This result indicates that there was no complementation. Interestingly, when the mutants with a mutation in the site A 

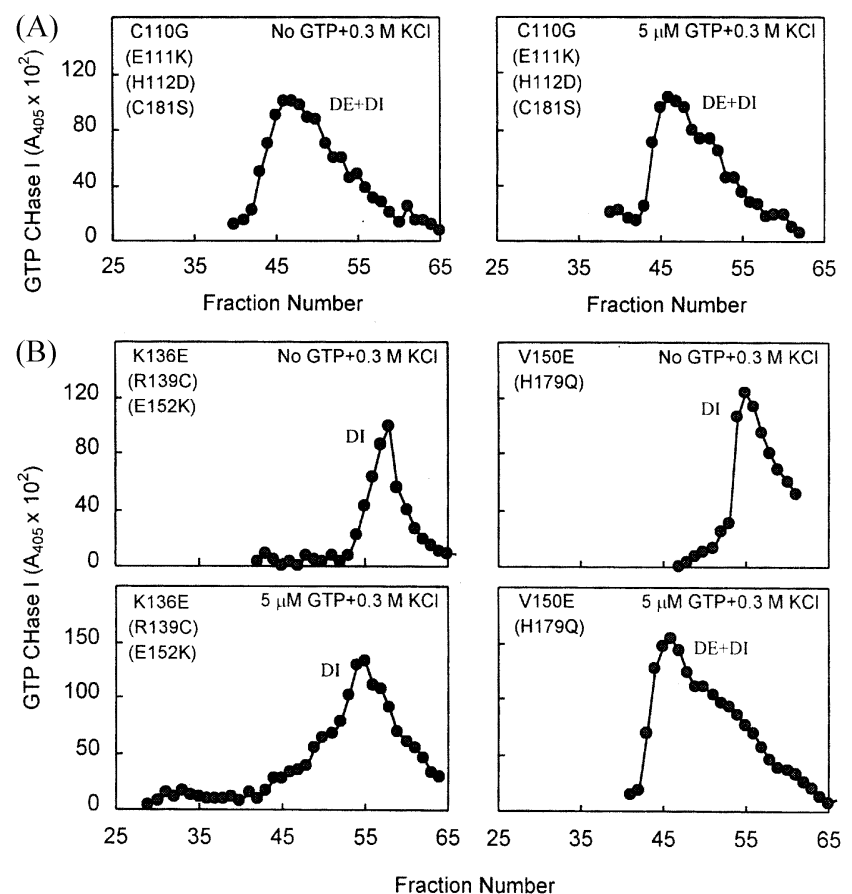

Fig. 3. Gel filtration of GTP CHase I mutants in the presence of $0.3 \mathrm{M} \mathrm{KCl}$. (A) Mutants that are relatively resistant to dissociation in high-salt. (B) Mutants that dissociated into subunit form. GTP CHase I mutant enzymes were applied to a Superdex column that was equilibrated with $50 \mathrm{mM}$ Tris- $\mathrm{HCl}(\mathrm{pH} \mathrm{8.0)}$ and $0.3 \mathrm{M} \mathrm{KCl}$ in the presence or absence of GTP. The enzymes were detected by ELISA using an antibody against GTP CHase I. DE: decamer, DI: dimer, DE+DI: equilibrium between decamer and dimer.

group (V150E, E152K, H179Q, and R185G) were mixed with other mutants (L134Q, S135C, K136E, and R139C), whose mutations were carried in the A' group, the mixtures showed good complementation (Table 2b). The R65L mutant, located in the B site, also acquired a functionally active site when reconstituted with mutants of the A' group (Table 2c). The hybrid between mutants in the A site and R651 of the B site resulted in no increase in activity (Table $2 \mathrm{c}$ ). This implies that the $\mathrm{A}$ and $\mathrm{B}$ monomers did not dissociate even in the presence of $0.3 \mathrm{M} \mathrm{KCl}$. Conversely, no negative complementation was observed from reconstitution between the wild-type and any of the inactive mutants (data not shown). These reconstitution experiments provide compelling evidence that the $\mathrm{A}$ and $\mathrm{B}$ monomers are tightly associated, and the active site is shared by one dimer that is composed of tightly linked $A+B$ monomers and another dimer containing A monomer.

\section{Discussion}

A series of gel filtration experiments was performed to examine how the wild-type and mutant enzymes could dissociate into subunits in the presence or absence of highsalt. The wild-type enzyme migrated as a catalytically active
Table 2a. Complementation studies between A or A' functional groups of E. coli GTP CHase I mutants

\begin{tabular}{|c|c|c|c|}
\hline \multirow[b]{2}{*}{$\begin{array}{l}\text { Enzyme pairs } \\
\text { tested }\end{array}$} & \multicolumn{3}{|c|}{ Specific activity (\% WT) } \\
\hline & Expected $^{a}$ & Observed & $\begin{array}{c}\text { Observed/ } \\
\text { Expected } \\
\text { ratio }\end{array}$ \\
\hline (A) $\quad(\mathrm{A})$ & & & \\
\hline $\mathrm{V} 150 \mathrm{E}+\mathrm{E} 152 \mathrm{~K}$ & 1.63 & 1.6 & 0.98 \\
\hline V150E + H179Q & 2.0 & 2.04 & 1.02 \\
\hline $\mathrm{V} 150 \mathrm{E}+\mathrm{R} 185 \mathrm{G}$ & 3.1 & 2.95 & 0.95 \\
\hline $\mathrm{E} 152 \mathrm{~K}+\mathrm{H} 179 \mathrm{Q}$ & 0.43 & 0.38 & 0.89 \\
\hline $\mathrm{E} 152 \mathrm{~K}+\mathrm{R} 185 \mathrm{G}$ & 1.53 & 1.38 & 0.9 \\
\hline H179Q + R185G & 1.9 & 1.82 & 0.96 \\
\hline$\left(\mathrm{A}^{\prime}\right) \quad\left(\mathrm{A}^{\prime}\right)$ & & & \\
\hline L134Q + S135C & 1.29 & 1.32 & 1.02 \\
\hline L134Q + K136E & 1.06 & 1.03 & 0.97 \\
\hline L134Q + R139C & 15.9 & 15.7 & 0.99 \\
\hline$S 135 C+K 135 E$ & 0.49 & 0.43 & 0.88 \\
\hline $\mathrm{S} 135 \mathrm{C}+\mathrm{R} 139 \mathrm{C}$ & 15.3 & 14.9 & 0.97 \\
\hline $\mathrm{K} 135 \mathrm{E}+\mathrm{R} 139 \mathrm{C}$ & 15.1 & 13.9 & 0.92 \\
\hline
\end{tabular}

Each mutant enzyme $(20 \mu \mathrm{g})$ was preincubated in $50 \mathrm{mM}$ Tris$\mathrm{HCl}(\mathrm{pH} 8.0)+0.3 \mathrm{M} \mathrm{KCl}$ for $1 \mathrm{~h}$ at $4^{\circ} \mathrm{C}$. After the mutant enzymes were mixed, the activity was measured by the standard fluorescence assay. Aliquots $(10 \mu \mathrm{l})$ of the mixture were added to the assay solution in which the final concentration of enzymes was $0.4 \mu \mathrm{g} / \mathrm{ml}$. ${ }^{a}$ Expected activity was the mean of the activities of each single mutant.

protein of $250 \mathrm{kDa}$, as expected. However, it migrated to the position of about $120 \mathrm{kDa}$ in the presence of $0.3 \mathrm{M} \mathrm{KCl}$. This did not correspond well with the previous data, in which the predominant molecular species of the wild-type enzyme in the high-salt condition $(0.3 \mathrm{M} \mathrm{KCl})$ was $50 \mathrm{kDa}$ (Yim and Brown, 1976). This discrepancy seems to be a result of the differences in the preincubation time, column used, running time, and other factors. We suspect that the proteins of $120 \mathrm{kDa}$ were intermediate forms under a rapid equilibrium between decamers and dimers in the absence of GTP. In general, the protein dissociation/reassociation is influenced by protein concentration, ligands, $\mathrm{pH}$, temperature, and ionic strength (Malinowski and Fridovich, 1979; Lewis and Youle, 1986; Attri et al., 1991). A similar phenomenon was reported with E. coli adenylosuccinate synthetase, the first committed enzyme in the conversion of IMP to AMP in purine biosynthesis. No two distinct species of monomer and dimer were observed in the analytical ultracentrifugation. Suggestions were made that a rapid equilibrium exists between the monomers and dimers in the absence of ligand (Wang et al., 1997).

Interestingly, the mutant proteins that completely or partly dissociated into dimers in the presence of $0.3 \mathrm{M} \mathrm{KCl}$ showed good complementation in the reconstitution experiment. The ratio of dimer to oligomer also seemed to be closely related to 
Table 2b. Complementation studies between A and A' functional groups of E. coli GTP CHase I mutants

\begin{tabular}{clcc}
\hline & \multicolumn{3}{c}{ Specific acitivity (\% WT) } \\
\cline { 2 - 4 } $\begin{array}{c}\text { Enzyme pairs } \\
\text { tested }\end{array}$ & Expected & Observed & $\begin{array}{c}\text { Observed/ } \\
\text { Expected } \\
\text { ratio }\end{array}$ \\
\hline (A') (A) & & & \\
L134Q + V150E & 2.5 & 5.6 & 2.2 \\
L134Q + E152K & 0.96 & 2.0 & 2.1 \\
L134Q + H179Q & 1.3 & 4.5 & 3.4 \\
L134Q + R185G & 2.4 & 6.5 & 2.7 \\
& & & \\
S135C + V150E & 1.2 & 6.5 & 5.2 \\
S135C + E152K & 0.39 & 2.9 & 7.4 \\
S135C + H179Q & 0.76 & 3.5 & 4.6 \\
S135C + R185G & 1.9 & 6.9 & 3.7 \\
K135E + V150E & 1.7 & 15 & 8.7 \\
K136E + E152K & 0.16 & 14.3 & 89 \\
K136E + H179Q & 0.53 & 11 & 21 \\
K136E + R185G & 1.6 & 10 & 6.4 \\
R139C + V150E & 16 & 23 & 1.4 \\
R139C + E152K & 15 & 23 & 1.5 \\
R139C + H179Q & 15 & 22 & 1.4 \\
R139C + R185G & 16 & 25 & 1.5 \\
\hline
\end{tabular}

Reconstitution assays were carried out as described in Table 2a.

the level of complementation. R65L, L134Q, and S135C, which were present as partly dissociated dimers, exhibited a relatively low level of complementation, compared to the completely dissociated mutants (such as K136E, E152K, and H179Q). Because the pretreatment for the dissociation was performed in $0.3 \mathrm{M} \mathrm{KCl}$, the mutants that are resistant to dissociation (C110G, E111K, H112D, and C181S) could not form the hybrid protein that exhibits the restored activity. Considering the fact that the dissociation is a prerequisite for the formation of an active hybrid enzyme, it is now clear that the active site of GTP CHase I is composed of different dimers.

The fact that a low concentration of GTP $(5 \mu \mathrm{M})$ can convert dimers in high-salt into a decamer suggests that GTP can stabilize the native decameric structure by playing the role of a linker between dimers. Even without high salt, the K136E and R139C mutants, whose mutations are located in the A' functional group, had a completely dimeric structure (50 $\mathrm{kDa}$ ). They also remained as dimers, despite the addition of GTP in the presence of high-salt (Fig. 3B). Thus, Lys136 and Arg139 should play an essential role in the binding of GTP through the interaction with $\gamma$-phosphate. The E111K, S135C, and $\mathrm{E} 152 \mathrm{~K}$ mutants formed an abnormal didecamer aggregate (Fig 2A). This result implies that these residues are also important in stabilizing the native decamer. Glu111 and
Table 2c. Complementation studies between B functional groups and A or A groups of E. coli GTP CHase I mutants

\begin{tabular}{cccc}
\hline & \multicolumn{3}{c}{ Specific activity (\% WT) } \\
\cline { 2 - 4 } $\begin{array}{c}\text { Enzyme pairs } \\
\text { tested }\end{array}$ & Expected & Observed & $\begin{array}{c}\text { Observed/ } \\
\text { Expected } \\
\text { ratio }\end{array}$ \\
\hline (A) (B) & & & \\
L134Q + R65L & 7.93 & 10.4 & 1.3 \\
S135C + R65L & 7.36 & 10.6 & 1.4 \\
K136E + R65L & 7.13 & 10.3 & 1.4 \\
R139C + R65L & 22.0 & 24.4 & 1.1 \\
\hline (A') (B') & & & \\
V150E + R65L & 8.6 & 8.9 & 1.03 \\
E152K + R65L & 7.0 & 7.14 & 1.02 \\
H179Q + R65L & 7.4 & 7.47 & 1.01 \\
R185G + R65L & 8.5 & 8.75 & 1.03 \\
\hline
\end{tabular}

Reconstitution assays were carried out as described in Table 2a.

Glu152 are the only proposed constituents of the negative charge in the active site (Nar et al., 1995b), where basic amino acid residues are prevalent for neutralizing the triphosphate of GTP. The replacement of Glu with Lys could cause an electrostatic repulsion that would lead to the abnormal aggregation of the enzyme.

The crystal-packing arrangement that was obtained by electron microscopy and X-ray data showed that the GTP CHase I complex is a doughnut-shaped decamer that consists of a pentamer of tightly associated dimers. Our results showed that the GTP CHase I complex could dissociate into catalytically inactive dimers at high-salt. Also, the dimers consisted of pairs of the A and B monomers, which implies that the A-B dimer should be a unit for oligomerization of the enzyme. Our biochemical data (obtained by gel filtration and reconstitution experiments) also provide compelling evidence that the active site is located between the dimers. In addition, the amino acids, determined to be important in catalysis and oligomerization, support the crystallographic data proposed by Nar et al. (1995b).

Acknowledgments This work was supported in part by the Seoul National University (1997-1998) and the National Creative Research Initiative Program of the Korean Ministry of Science and Technology, Republic of Korea.

\section{References}

Ahn, C., Byun, J. and Yim J. (1997) Purification, cloning, and functional expression of dihydroneopterin triphosphate 2'epimerase from Escherichia coli. J. Biol. Chem. 272, 1532315328.

Ahn, C., Park, S. I., Kim, J. M. and Yim J. (1995) Affinity labeling of $E$. coli GTP cyclohydrolase I by a dialdehyde 
derivative of guanosine triphosphate. J. Biochem. Mol. Biol. 28, 72-78.

Attri, A. K., Lewis, M. S. and Korn, E. D. (1991) The formation of actin oligomers studied by analytical ultracentrifugation. $J$. Biol. Chem. 266, 6815-6824.

Auerbach, G., Herrmann, A., Bracher, A., Bader, G., Gutlich, M., Fischer, M., Neukamm, M., Garrido-Franco, M., Richardson, J., Nar, H., Huber, R. and Bacher, A. (2000) Zinc plays a key role in human and bacterial GTP cyclohydrolase I. Proc. Natl. Acad. Sci. USA 97, 13567-13572.

Brown, G. M. and Williamston, J. M. (1987) Biosynthesis of folic acid, riboflavin, thiamine, and pantothenic acid; in Escherichia coli and Salmonella typhimurium, Neidhardt, F. C. (ed.), Vol. 1, pp. 521-538, Am. Soc. Microbiol., Washington, DC.

Cha, K. W., Jacobson K. B. and Yim. J. (1991) Isolation and characterization of GTP cyclohydrolase I from mouse liver. Comparison of normal and the hph-1 mutant. J. Biol. Chem. 266, 12294-12300.

Frimpong, K. and Rodwell, V. W. (1994) The active site of hamster 3-hydroxy-3-methylglutaryl-CoA reductase resides at the subunit interface and incorporates catalytically essential acidic residues from separate polypeptides. J. Biol. Chem. 269, 1217-1221.

Fukushima, K., Richter, W. E. Jr. and Shiota, T. (1977) Partial purification of 6-(D-erythro-1',2',3'-trihydroxypropyl)-7,8dihydropterin triphosphate synthetase from chicken liver. $J$. Biol. Chem. 252, 5750-5755.

Katzenmeier, G., Schmid, C. and Bacher, A. (1990) Cloning and expression of the putative gene coding for GTP cyclohydrolase I from Escherichia coli. FEMS Microbiol. Lett. 66, 231-234.

Katzenmeier, G., Schmid, C., Kellerman, J., Lottspeich, F. and Bacher, A. (1991) Biosynthesis of tetrahydrofolate. Sequence of GTP cyclohydrolase I from Escherichia coli. Biol. Chem. Hoppe Seyler 372, 991-997.

Kim, S. I., Kim, S. J., Leem, S. H., Oh, K. H., Kim, S. H. and Park, Y. M. (2001) Site-directed mutagenesis of two cysteines $(155,202)$ in catechol 1,2-dioxygenase $I_{1}$ of Acinetobacter lwoffii K24. J. Biochem. Mol. Biol. 34, 172-175.

Kim, S. Y., Song, E. J., Chang, K. H., Kim, E., Chae, S. K., Lee, H. and Lee, K. J. (2001) Oligomeric Structure Determine the Biochemical Characteristics of Human Nucleoside Diphosphate Kinases. J. Biochem. Mol. Biol. 34, 355-364.

Lee, J., Seo, H. Y., Jeon, E. S., Park, O. S., Lee, K. M., Park, C. U. and Kim, K. S. (2001) Cooperative activity of subunits of human ferritin heteropolymers in Escherichia coli. J. Biochem. Mol. Biol. 34, 365-370.

Lewis, M. S. and Youle, R. J. (1986) Ricin subunit association. Thermodynamics and the role of the disulfide bond in toxicity. J. Biol. Chem. 261, 11571-11577.

Maley, F., Pedersen-Lane, J. and Changchien L. (1995) Complete restoration of activity to inactive mutants of Escherichia coli thymidylate synthase: evidence that $E$. coli thymidylate synthase is a half-the-sites activity enzyme. Biochemistry 34,
1469-1473.

Malinowski, D. P. and Fridovich, I. (1979) Subunit association and side-chain reactivities of bovine erythrocyte superoxide dismutase in denaturing solvents. Biochemistry 18, 5055-5060

Mancini, G., Carbonara, A. O. and Heremans, J. F. (1965) Immunochemical quantitation of antigens by single radial immunodiffusion. Immunochem. 2, 235-254.

Meining, W., Bacher, A., Bachmann, L., Schmid, C., Weinkauf, S., Huber, R. and Nar, H. (1995) Elucidation of crystal packing by X-ray diffraction and freeze-etching electron microscopy. Studies on GTP cyclohydrolase I of Escherichia coli. J. Mol. Biol. 253, 208-218.

Nar, H., Huber, R., Auerbach, G., Fischer, M., Hosl, C., Ritz, H., Racher, A., Meining, W., Eberhardt, S. and Bacher, A. (1995b) Active site topology and reaction mechanism of GTP cyclohydrolase I. Proc. Natl. Acad. Sci. USA 92, 12120-12125.

Nar, H., Huber, R., Meining, W., Schmid, C., Weinkauf, S. and Bacher, A. (1995a) Atomic structure of GTP cyclohydrolase I. Structure 3, 459-466.

Nichol, C. A., Smith, G. K. and Dutch, D. S. (1985) Biosynthesis and metabolism of tetrahydrobiopterin and molybdopterin. Annu. Rev. Biochem. 54, 729-764.

Ozturk, D. H., Dorfman, R. H., Scapin, G., Sacchettini, J. C. and Grubmeyer, C. (1995) Structure and function of Salmonella typhimurium orotate phosphoribosyltransferase: protein complementation reveals shared active sites. Biochemistry 34, 10765-10770.

Schmid, C., Ladenstein, R., Lueke, H., Huber, R. and Bacher, A. (1992) Crystallization and preliminary crystallographic characterization of GTP cyclohydrolase I from Escherichia coli. J. Mol. Biol. 226, 1279-1281.

Shiota, Y., Palumbo, M. P. and Tsal, L. (1967) A chemically prepared formamidopyrimidine derivative of guanosine triphosphate as a possible intermediate in pteridine biosynthesis. J. Biol. Chem. 242, 1961-1969.

Tobias, K. E. and Kahana, C. (1993) Intersubunit location of the active site of mammalian ornithine decarboxylase as determined by hybridization of site-directed mutants. Biochemistry 22, 5842-5847.

Wang, W., Gorrell, A., Honzatko, R. B. and Fromm, H. J. (1997) A study of Escherichia coli adenylosuccinate synthetase association states and the interface residues of the homodimer. J. Biol. Chem. 272, 7078-7084.

Wente, S. R. and Schachman, H. K. (1987) Shared active sites in oligomeric enzymes: model studies with defective mutants of aspartate transcarbamoylase produced by site-directed mutagenesis. Proc. Natl. Acad. Sci. USA 84, 31-35.

Yim, J. J. and Brown, G. M. (1976) Characteristics of guanosine triphosphate cyclohydrolase I purified from Escherichia coli. J. Biol. Chem. 251, 5087-5094.

Yuckenberg, P. D., Witney, F., Geisselsoder, F. and McClary, G. (1991) Directed Mutagenesis (McPherson, M. J. ed.) pp. 27-48, Oxford Univ. Press, New York. 